\title{
The Social Relation of Muslims and Christians in Sidorejo Village, Umbulsari District, Jember Regency
}

\author{
Ahmad Zainuri \\ Mahasiswa Pascasarjana UIN Sunan Kalijaga Yogyakarta, Jl. Laksda Adisucipto, Papringan, Caturtunggal, Kec. \\ Depok, Kab. Sleman, DI Yogyakarta 55281. ahmadsultanzain1986@gmail.com
}

\begin{abstract}
This study aims to explore social relations in Sidorejo Village, Umbulsari District, Jember Regency. Central to this study is the relations and efforts to maintain harmony between Muslims and Christians in Sidorejo Village. The methodology in this study is qualitative methods using historical, religious and social approaches in-depth interview techniques and literature review analysis. The results of this study indicate that social solidarity among the people of Sidorejo in building social relations is very harmonious through several religious and social activities carried out together. Religious leaders and community leaders also participate in building harmony between Muslims and Christians in Sidorejo Village. In conclusion, the Sidorejo people enable to construct harmony and tackle social conflict through mediation before the conflict arises on the surface. Social relations are the key for the people of Sidorejo to build socialbased religious harmony, because the goal of building harmony is not theological but how social relations are developed. Some social activities carried out to build communality including building houses of worship. It is more important that the role of religious leaders becomes a central force in ensuring unity and harmony.
\end{abstract}

Keywords: relationship, harmony, Islam, Christian

\section{Relasi Sosial Muslim dan Kristiani di Desa Sidorejo, Kecamatan Umbulsari, Kabupaten Jember}

\begin{abstract}
Abstrak
Penelitian ini bertujuan untuk menggali sebuah relasi sosial dalam masyarakat Desa Sidorejo, Kecamatan Umbulsari, Kabupaten Jember. Titik fokus permasalahan yang ingin disampaikan dalam penelitian ini ialah bagaimana relasi dan upaya merawat keharmonisan antara Muslim dan Kristiani di Desa Sidorejo tersebut. Adapun metodologi dalam penelitian ini penulis menggunakan metode kualitatif dengan pendekatan sejarah, agama dan sosial secara mendalam dengan teknik wawancara dan analisa kajian pustaka. Hasil dari penelitian ini menunjukkan bahwa masyarakat Sidorejo dalam membangun relasi sosial, solidaritas sosial sangat rukun dan harmonis, terbukti dengan adanya beberapa kegiatan agama, sosial dilakukan secara bersama-sama. Tiada lain tiada bukan, peran tokoh agama, tokoh masyatakat juga ikutserta dalam membangun kerukunan antara Muslim dan Kristiani di Desa Sidorejo. Kesimpulannya bahwa hubungan kehidupan masyarakat Sidorejo begitu rukun dan harmonis, resolusi konflik selalu dimunculkan sebagai mediasi sebelum konflik itu timbul di permukaan. Relasi sosial menjadi kunci bagi masyarakat Sidorejo untuk membagun kerukunan agama berbasis sosial, karena tujuan membangun keharmonisan bukan dari teologisnya melainkan bagaimana hubungan sosialnya, dan ini terbukti banyak kegiatan sosial yang dilakukan untuk membangun kebersamaan, terutama membangun rumah ibadah. Terpenting lagi bahwa peran tokoh agama menjadi kekuatan sentral dalam menyatukan dan merawat kebersamaan dalam perbedaan demi mewujudkan Sidorejo yang rukun, tentram dan harmonis.
\end{abstract}

Kata Kunci: relasi, harmonis, Islam, Kristen

* Naskah diterima Agustus 2021, direvisi Oktober 2021, dan disetujui untuk diterbitkan November 2021

Dialog, 44(2), 2021, 245-264

https://jurnaldialog.kemenag.go.id,p-ISSN: 0126-396X, e-ISSN: 2715-6230

This is open access article under CC BY-NC-SA-License

(https://creativecommons.org/license/by-nc-sa/4.0/)

Dialog Vol. 44, No.2, Desember 2021

245 


\section{A. Pendahuluan}

Indonesia merupakan negara yang mempunyai tingkat pluralitas yang cukup mapan. Hal ini terbukti dengan aspek-aspek fundamental-primordial bisa hidup dan eksis bersamaan dalam satu naungan Negara Kesatuan Republik Indonesia. Dalam urusan kepercayaan, Indonesia memiliki sebuah konsepsi ideal tentang gagasan besar berkeyakinan dan beragama yang dilindungi oleh undang-undang sebagai landasan konstitusional yang sah dan diakui keabsahannya. Selain itu yang dapat dijadikan patokan atas keberagaman terbukti dalam aspek lain seperti suku, ras, budaya dan lain sebagainya yang kebebasan ekspresinya sama-sama diperolehkan atas dasar undang-undang yang berlaku di Indonesia.

Pemahaman pluralitas dan keberagaman di Indonesia bukan wacana baru lagi dalam praktik atau pelaksanaanya. Karakteristik keberagaman dalam hal primordial-elementer secara sederhana merupakan makanan sehari-hari bagi bangsa Indonesia secara umum. Anggapan semacam ini merupakan konstruksi berfikir ideal sekaligus juga menjadi harapan atau ekspektasi banyak orang dalam upaya mewujudkan negara yang adil, makmur, sejahtera dan damai. Ada beberapa yang seolah memberikan pengertian yang berbeda bahwa negara Indonesia belum benar-benar dewasa dalam menerima pluralitas sebagai nafas-yang terkadang dalam beberapa kasus belakangan sebagai bukti atau contoh tindakan intoleransi yang berujung pada tindakan radikalismeekstremisme yang menyebabkan perilaku teror yang membahayakan banyak kalangan (Rahman, 2021).

Dalam hidup beragama di Indonesia seharusnya dijalani dalam semangat dialog, karena dengan dialog termanifestasikan sebuah kemampuan untuk bersikap toleran-mampu menerima kemajemukan dan kebebasan - dan bersahabat. Ini adalah sikap menerima perbedaan walaupun ada sejumlah hal yang mereka lakukan tidak sejalan dengan nilai hidup dalam beragama. Sejatinya dalam toleransi ada sikap yang lebih dari sekadar mempersilahkan, tapi keterbukaan yang memang panggilan dalam hati. Harusnya agama yang mereka hayati ialah agama yang membawa pada kedalaman makna untuk termanifes dalam aksi. Sehingga dialog dan ramah tamah dalam beragama, akan timbul untuk saling mengasihi. Jika perihal dalam penghayatan agama hilang dari kehidupan beragama, maka orang-orang beragama lebih beresiko terdampak berbagai kepentingan yang menyingkirkan berbagai keinginan untuk berbagi ruang persahabatan dengan orang lain (Cornelius Kaha, 2020).

Sikap toleransi beragama itu perlu kemudian menjadi salah satu tali hubung antarumat yang memang berbeda. Ini memang menjadi keniscayaan dalam realitas sosial beragama. Jadi jangan jadikan keadaan kemudian memaksa landasan pikiran untuk sama dan membuat keragaman menjadi saling haram-haraman dan saling membenci satu sama lain. Sosial mengajarkan kita bahwa perlu kemudian pranata sosial harus terus dibangun agar terciptanya masyarakat yang rukun dan harmonis. Harmonis dalam hal apa? Banyak hal pastinya. Misalnya menyikapi keberagaman agama, kita semua harus luwes dan saling memahami bahwa mereka mempunyai keberagamaan sendiri, sehingga rumus dalam hidup beragama ialah membangun sisi yang intim menjadi umum untuk bisa saling memahamkan.

Dwi Ananta mencatat sikap toleransi beragama adalah sabar dan menahan diri untuk tidak mengganggu dan tidak melecehkan agama atau sistem keyakinan dan ibadah penganut agama-agama lain. Konsep dari toleransi mengarah kepada sikap terbuka dan mau mengakui adanya berbagai macam perbedaan, baik dari sisi suku bangsa, warna kulit, bahasa, adatistiadat, budaya, bahasa, serta agama. Bagi manusia, sudah selayaknya untuk mengikuti petunjuk Tuhan dalam menghadapi perbedaan-perbedaan itu. Karena Tuhan senantiasa mengingatkan kita akan keragaman manusia yang tidak melihat dari latar belakangnya. Untuk mengembangkan sikap toleransi secara 
umum, dapat kita mulai terlebih dahulu dengan bagaimana kemampuan kita mengelola dan menyikapi perbedaan (pendapat) yang mungkin terjadi pada keluarga kita. Sikap toleransi dimulai dengan cara membangun kebersamaan atau keharmonisan dan menyadari adanya perbedaan. Sekaligus menyadari pula bahwa kita semua adalah bersaudara. Maka akan timbul rasa kasih sayang, saling pengertian dan pada akhirnya akan bermuara pada sikap toleran (Ananta Devy, 2009).

Ismail Pangeran menjelaskan toleransi ialah suatu sikap atau sifat dari seseorang untuk membiarkan kebebasan kepada orang lain serta memberikan kebenaran atas perbedaan tersebut sebagai pengakuan hakhak asasi manusia. Pelaksanaan sikap toleransi ini harus didasari sikap kelapangan dada terhadap orang lain dengan memperhatikan prinsip-prinsip yang dipegang sendiri, yakni tanpa mengorbankan prinsip-prinsip baku dalam keyakinan agama kita sendiri. Jelas bahwa toleransi terjadi dan berlaku karena terdapat perbedaan prinsip, dan menghormati perbedaan prinsip orang lain tanpa membedakan prinsipnya dengan diri kita sendiri. Sikap toleransi itu harus bisa menciptakan ekspresi keberagamaan yang indah dan rukun, menurut Ismail ada beberapa unsur yaitu; memberikan kebebasan dan kemerdekaan, mengakui hak setiap orang, menghormati keyakinan orang lain, dan saling mengerti (Pangeran, 2017). Hakikat toleransi menurut Fitriani yaitu usaha dalam hal kebaikan, khusunya pada kemajemukan agama yang memiliki tujuan tercapainya kerukunan, baik intern agama maupun antaragama. Tujuan kerukunan antarumat agama dibagi menjadi empat, yakni; meningkatkan keimanan dan ketakwaan terhadap masing-masing agama, mewujudkan stabilitas nasional yang baik, menjunjung dan menyukseskan pembangunan, dan terakhir, memelihara dan mempererat rasa persaudaraan antarumat beragama (Fitriani, 2020).

Seluruh umat beragama harus memberikan kontribusi yang nyata bagi pembangunan nasional yang dilaksanakan bangsa Indonesia. Nilai-nilai religius harus dapat memberikan motivasi positif dan menjadi arah tujuan dalam seluruh kegiatan pembangunan di Indonesia. Peraturan dan kerjasama antarumat beragama mutlak diperlakukan. Namun, soal hubungan antarumat beragama adalah soal yang sangat peka. Banyak kejadian yang kadang mengarah kepada permusuhan dan penghancuran aset nasional disebabkan isu yang dikaitkan dengan hubungan antaragama. Walaupun sebenarnya setiap umat agama mengajarkan kerukunan antarmanusia dan antarumat beragama (Vinkasari et al., 2020). Karena memang setiap agama yang ada di dunia ini lahir berbeda-beda, hal ini disebabkan karena setiap agama memiliki latar belakang budaya yang berbeda pula. Terlepas mengenai perbedaan yang ada, munculnya masing-masing agama memiliki prinsip yang sama. Kesamaan tersebut merupakan sumber dan tujuan dan agama itu sendiri yakni sama-sama bersumber dan tertuju kepada Tuhan Yang Maha Esa (Huda \& Sinta Ilva Sari, 2020).

Ketika melihat kompleksitas masyarakat multikultural yang ada di arus bawah, mereka senantiasa tidak pernah terpengaruh dari radikalitas beragama. Isu fanatis kelompok beragama yang menggema dalam akhir-akhir ini tidak menjadikan masyarakat itu enggan tidak rukun. Karena ini sudah terikat dengan sebuah tradisi masyarakat. Kalau dalam studinya Durkheim bahwa solidaritas itu terbangun dengan adanya sebuah ikatan keluarga, adat dan warisan, yang kemudian disebut sebagai solidaritas mekanik. Ini pun terjadi pada masyarakat Sidorejo di Kabupaten Jember. Maclever dalam Casram menjelaskan masyarakat dibentuk oleh struktur yang tidak kelihatan dan merupakan kumpulan dari beragam hubungan manusia yang dibangun dan diubah oleh manusia itu sendiri. Masyarakat bergerak dinamis sesuai dengan perkembangan zaman. Di dalam masyarakat sederhana atau primitif/ tradisional, manusia memiliki karakteristik 
yang serba homogen baik dalam budaya, agama maupun struktur sosial (Casram, 2016).

Masyarakat kompleks atau masyarakat multikultural tersusun dari keanekaragaman budaya, masyarakat dan struktur sosial. Keanekaragaman adalah fakta yang tidak bisa dielakkan dalam kehidupan kolektif dan tidak bisa diharapkan eksistensinya atau tidak dapat ditekan tanpa tingkat kekerasan yang bisa diterima. Semua dibangun dengan adanya spiritualitas saling keterikatan, yang pasti tidak lepas dari koridor toleransi. Dalam tinjauan toleransi spiritual, Akmansyah memberi catatan bahwa konsep dasar toleransi spiritual ialah; pertama, objek toleransi spiritual ialah perbedaan atau pertentangan antar keyakinan atau kepercayaan. Kedua, sikap toleransi spiritual bukan sikap menyeragamkan atau menyatukan perbedaan keyakinan atau kepercayaan, atau mensinkretisasikannya, melainkan menenggang rasa terhadap perbedaan atau pertentangan antarkeyakinan atau kepercayaan tersebut. Ketiga, toleransi spiritual dibentuk oleh dimensi-dimensi kebatinan atau keruhanian, seperti cinta, kondisi spiritual, kedudukan spiritual. Jadi, toleransi spiritual tetap mempertahankan prinsip-prinsip pluralis dan multikulturalis, serta tentu saja tidak dengan sendirinya dihayati secara sama dan utuh, melainkan bervariasi dan penuh nuansa (M. Akmansyah, 2016).

\section{B. Metode Penelitian}

Penelitian ini menggunakan pendekatan sejarah, sosial dan agama yang akan digali secara mendalam atau deep interview pada informan dan ditambah dengan menggali serta menganalisa berbagai sumber rujukan dalam beberapa referensi yang terkait sebagai data pendukung yang bersifat primer maupun skunder. Dalam fokus kajian ini penulis akan mengungkapkan lokus objek penelitian yakni Desa Sidorejo, kemudian dilanjut dengan fokus kedua yakni bagaimana relasi sosial di Desa Sidorejo dan fokus ketiga yakni bagaimana upaya merawat keharmonisan pada masyarakat Desa Sidorejo. Sehingga tujuan akhir dan keunikan daripada penelitian ini ialah mencari titik temu sebuah konsep keharmonisan masyarakat Desa Sidorejo sehingga bisa digunakan sebagai salah satu rumus keharmonisan, role model dalam membingkai kehidupan majemuknya agama pada masyarakat Indonesia.

Dalam penelitian ini, untuk memberikan konsep dalam meninjau kajian empirisitas penulis menggunakan teori solidaritas sosial milik Emile Durkheim. Ia membedakan antara kelompok yang didasarkan pada solidaritas mekanik dan yang didasarkan pada solidaritas organik. Solidaritas mekanik merupakan ciri yang menandai masyarakat yang masih sederhana, yang oleh Durkheim dinamakan segmental. Dalam masyarakat yang menganut solidaritas mekanik, yang diutamakan ialah persamaan perilaku dan sikap, perbedaan tidak dibenarkan. Menurut Durkheim, seluruh warga masyarakat diikat oleh apa yang dinamakannya kesadaran kolektif, hati nurani kolektif (collective consience)-suatu kesadaran bersama yang mencakup keseluruhan kepercayaan dan perasaan kelompok, dan bersifat ekstern dan memaksa. Sanksi terhadap pelanggaran hukum di sini bersifat represif; barangsiapa melanggar solidaritas sosial akan dikenai hukuman pidana. Kesadaran bersama tersebut mempersatukan para warga masyarakat, dan hukuman terhadap pelanggar aturan bertujuan agar ketidakseimbangan yang diakibatkan oleh kejahatan tersebut dapat dipulihkan kembali. Solidaritas Organik merupakan bentuk solidaritas yang mengikat masyarakat kompleks yang telah mengenal pembagian kerja yang rinci dan dipersatukan oleh kesalingtergantungan antarbagian. Tiap anggota menjalankan peran yang berbeda, dan di antara berbagai peran yang ada terdapat saling ketergantungan. Karena adanya saling ketergantungan ini maka ketidakhadiran pemegang peran tertentu akan mengakibatkan gangguan pada kelangsungan hidup masyarakat (Sunarto, 2004). 
Penulis dengan ini menggunakan teori solidaritas sosial dari Emile Durkheim sebagai kacamata untuk melihat realitas masyarakat Desa Sidorejo yang unik dan beragam agama. Dalam kehidupan seharihari mereka begitu solid, meski beragam agama tidak mengurangi aktifitas masingmasing agama dalam menjalani peribadatan dan kehidupan bermasyarakat. Sehingga relevan ketika teori ini diterapkan dalam masyarakat Desa Sidorejo yang plural dengan agamanya. Solidaritas dalam kehidupan mereka ialah salah satu pondasi dalam menciptakan suasana yang harmonis, dan solidaritas masyarakat Sidorejo sangat rukun dengan membangun relasi sosial dalam bentuk-bentuk nyata untuk saling bahu-membahu kerja sama, kerja bakti dan gotong royong. Solidaritas tersebut bisa berbentuk gotong royong-membangun tempat ibadah, bersih desa, dan membangun desa.

Tidak hanya solidaritas sosial, melainkan bagaimana upaya itu bisa membangun keharmonisan dalam beragama, kuncinya ialah adanya interaksi sosial dan keterbukaan, sehingga penulis menggunakan konsep teori Interaksi Sosial Gillin dan Gillin. Interaksi Sosial merupakan hubungan-hubungan sosial yang dinamis yang menyangkut hubungan antara individu dengan individu, kelompok dengan kelompok maupun sebaliknya. Kehidupan bersama dalam pengertian interaksi sosial tersebut dapat diartikan salah satunya adalah terjadinya kerukunan, karena melalui interaksi sosial, masyarakat melakukan pola hubungan seperti menegur, menyapa, dan saling berbicara. Penulis dalam melihat sebuah realitas masyarakat Desa Sidorejo yang terdapat dua agama yakni Islam dan Kristen dan hubungan mereka yang terjalin dengan harmonis, menggunakan kacamata teori Interaksi Sosial dalam melihat realitas sosial dalam masyarakat tersebut, terutama tentang bagaimana upaya umat Muslim dan Kristiani dalam merawat keharmonisan di Desa Sidorejo. Penulis merujuk pada Gillin dan Gillin dalam membagi proses terjadinya interaksi dalam dua bagian, yakni pola hubungan asosiatif dan pola hubungan dissosiatif. Dalam hal ini penulis lebih menggunakan pola asosiatif, karena dianggap relevan dengan konteks penelitian, yakni tentang Relasi Sosial Umat Muslim dan Kristiani di Desa Sidorejo. Bentuk hubungan assosiatif yang penulis terapkan meliputi akomodasi dan asimilasi. Dalam hal ini penulis menggunakan tiga bentuk, di antaranya kompromi, konsiliasi dan toleransi. Meskipun konteks yang dibahas keteraturan masyarakat atau yang dapat diartikan dengan tidak adanya sebuah konflik dalam kehidupan masyarakat (Soekanto \& Soelistyowati, 2017).

Dalam mengkaji tema penelitian yang telah disebutkan di atas, maka penulis menggunakan desain research yakni case study. Adapun studi kasus yang penulis jadikan sebagai titik penelitian yakni Desa Sidorejo, desa yang berada di Kecamatan Umbulsari dengan dua agama yakni Islam dan Kristen, yang keduanya saling rukun dan harmonis dalam menjalani kehidupan bertetangga. Penelitian ini dilakukan kurang lebih dalam rentang 2-3 bulan di tahun 2019. Pendekatan yang penulis gunakan ialah pendekatan historis, social dan religious yakni Desa Sidorejo dengan masyarakat yang beragam agama yakni Islam dan Kristen dan keduanya ialah pasti agama pendatang dan secara sisi historis akan kami kupas dengan wawancara tokoh masyarakat/agama di Desa Sidorejo secara mendalam untuk mencari titik fokus utama yakni relasi sosial, agama dalam masyarakat Sidorejo. Dalam penggalian sumber data selama penelitian ialah menggunakan kedalaman dalam berwawancara atau deep interview dengan narasumber yang terkait mengenai bagaimana relasi sosial umat Muslim dan Kristiani di Desa Sidorejo dan bagaimana upaya umat Muslim dan Kristiani dalam merawat keharmonisan di Desa Sidorejo. Adapun sumber data yang kami dapatkan ialah dengan cara purposive pada informan dengan beberapa kriteria di antaranya; kepala desa, tokoh agama, tokoh masyarakat, perangkat desa dan pemuda. Sumber data yang didapatkan tanya jawab sambil tatap muka antara pewawancara 
dengan informan.

\section{Hasil dan Pembahasan Sejarah Desa Sidorejo}

Sejarah Desa Sidorejo dimulai dari permulaan gereja pertama yang dibangun dalam persekutuan kecil sebut saja kelompok persekutuan Kyai Dasimah, Kyai Midah, Khunti dan Samidah. Pergumulan Kyai Dasimah dan kawan-kawan adalah karena ayat Markus 1:1. Ayat ini tetap "gelap" yaitu tentang Yesus Kristus Anak Allah. Pada tahun 1836 mereka bertemu dengan seorang Indo-Belanda di Ngoro Jombang yang bernama Coenraat Laurens Coolins bekas seorang militer Belanda yang sudah pensiun lalu ditugaskan lagi menjadi Mandor blandongan ( Mandor Hutan) (Penyusun Desa Sidorejo, 2016).

Coenraat Laurens Coolins inilah yang memperkenalkan agama baru yang menjadi cikal bakal Gereja Kristen Jawi Wetan di Wilayah Jawa Timur dan sekitarnya. Setelah mendengar itu Kyai Dasimah dan sepuluh temannya datang ke Ngoro dengan satu misi yaitu "Ngulati Toyo Wening" yang berarti: Yesus Anak Allah. Tuan Coenraat Laurens Coolins mengajarkan Tiga Rapal, dan selama 5 tahun. Ajaran itu antara lain: Sahabat Kalih Welas, Pepakhen Sedoso dan Dongo Romo Kawulo. Pesan-pesan tokoh inilah yang merupakan titik awal terjadinya Desa Sidorejo di Jember Jawa Timur.

Dalam sejarah perkembangan Desa Sidorejo penyebaran agama Kristen dengan awal mula mencari permukiman baru yang lebih baik dengan cara membuka hutan. Kemudian datanglah rombongan yang pertama orang-orang dari Mojowarno dan Kediri serta daerah lainnya. Rombongan tersebut di antaranya adalah Pak Broso, Pak Leprayin, Pak Setu, Pak Brontodiwiryo dengan Pak Lipur di daerah Tunjung Putih (Tunjung Rejo). Pada tahun 1905 rombongan tersebut dengan bersama 21 KK meninggalkan Tunjung Putih menuju timur yang 14 KK ke Sebanen dan 7 KK menuju alas Wonorejo. Pak Lipur termasuk yang 14 KK dan membuka hutan di Sebanen, dan pada tahun 1909 karena di Sebanen akan dijadikan perluasan pabrik gula oleh
Belanda, maka dengan berat hati meninggalkan Sebanen ke arah timur $\pm 6 \mathrm{Km}$ menuju hutan Ndlarungan (sekarang Umbulrejo).

Pada tahun 1911-1914 datang lagi rombongan ke II dari Mojowarno dan Sidorejo Kecamatan Pare, Kabupaten Kediri. Sebanyak $21 \mathrm{KK}$ antara lain: Pak Markus, Pak Dirjo, Pak Dirham, Pak Yokanan dan yang lainnya. Kata Sidorejo bermula dari orang yang berasal dari Sidorejo Kecamatan Pare, Kabupaten Kediri. Maka dari itu atas pertimbangan inilah mereka sepakat memberi nama tanah babatannya yang baru dengan nama Sidorejo, sama dengan nama Sidorejo yang ada di Kecamatan Pare Kabupaten Kediri. Demikian juga karena begitu besar keinginan orang-orang atau warga tersebut untuk mendirikan Gereja, maka warga Kristen membuka lahan khusus yang dipersembahkan untuk kelangsungan Gereja berupa tanah lokasi Gereja yang sekarang ini ditempati dan tanah sawah seluas 8.260 Ha (Penyusun Desa Sidorejo, 2016).

Tempat ibadah merupakan salah satu tempat yang menjadi titik temu berkumpulnya para umat masing-masing agama. Bisa diartikan juga sebuah tempat yang digunakan oleh umat beragama untuk beribadah menurut ajaran agama atau kepercayaan mereka masing-masing ("Tempat Ibadah," 2021). Di Desa Sidorejo sendiri terdapat dua tempat ibadah, yakni masjid dan gereja. Dalam sejarah, berdirinya masing-masing tempat ibadah tersebut terlatarbelakangi dengan datangnya para perantau dari daerah lain yang kemudian menetap di Desa Sidorejo. Berdirinya tempat ibadah di Desa Sidorejo diawali dari berdirinya Gereja Kristen Jawi Wetan di sebelah sungai yang merupakan Gereja induk di Desa Sidorejo dan gereja terbesar di Umbulsari. Berdirinya gereja ini menjadi cikal bakal Dusun Krajan yang mayoritas Kristen. Setelah terbabatnya hutan di sebelah barat kantor desa yang sekarang menjadi Dusun Gumuk Kembar merupakan dusun mayoritas Muslim. Namun juga ada beberapa umat Kristiani di Gumuk Kembar. Setelah membabat hutan 
seorang tokoh agama Islam yang bernama Mistar Ali sekitar tahun 70-an mendirikan sebuah masjid di wilayah Dusun Gumuk Kembar.

\section{Relasi Sosial Muslim Kristiani di Desa Sidorejo}

Relasi sosial atau hubungan sosial merupakan hubungan timbal balik antara individu yang satu dengan individu yang lain, saling mempengaruhi dan didasarkan pada kesadaran untuk saling mendorong. Relasi sosial yang terjalin antara individu yang berlangsung dalam waktu yang relatif lama akan membentuk suatu pola, pola hubungan ini juga disebut sebagai pola relasi sosial. Relasi sosial dalam masyarakat juga terdiri dari berbagai macam bentuk, yaitu relasi assosiatif dan relasi dissosiatif. Relasi sosial assosiatif lebih bersifat positif yang berbentuk kerja sama, akomodasi, akulturasi dan asimilasi. Sedangkan relasi sosial dissosiatif lebih ke dalam bentuk persaingan, pertentangan, perselisihan. Kedua pola relasi sosial tersebut dapat dijumpai dalam kehidupan masyarakat, baik dalam kehidupan masyarakat yang sama (homogen), maupun kehidupan masyarakat yang beragam (heterogen) (Soekanto \& Soelistyowati, 2017).

Hubungan sosial dalam kehidupan masyarakat menyangkut agama sangat beragam. Karena dalam masyarakat ada kehidupan yang masih klasik dan ada yang sudah pra-industri yang sedang berkembang hari ini, sehingga kehidupan masyarakat yang terbingkai dengan pluralitas agama membuat masing-masing individu menaruh perhatian lebih bagaimana bisa menjalankan kehidupan bersama dalam masyarakat. Banyak fenomena-fenomena yang terjadi pada masyarakat dalam menjalin kehidupan yang rukun. Dalam realitas kehidupan masyarakat Sidorejo yang beragam agama, memungkinkan untuk setiap masyarakat mencoba menyatukan cara pandang yang berbeda menjadi satu dalam fungsi untuk membangun masyarakat Sidorejo yang rukun dan harmonis. Sehingga menjadikan cara hidup antarumat maupun antarpaham umat beragama saling bisa menerima keberbedaan dan keberadaan, bukan untuk saling mengakui siapa yang paling benar.

Ada beberapa realitas fenomena keagamaan dalam masyarakat kita, antara lain: Pertama, kebanyakan fenomena keagamaan dalam masyarakat kita masih bersifat formalistik, verbalistik dan simbolik. Kedua, terjadi cheos: yakni kondisi masyarakat yang tidak karu-karuan, dikacaukan oleh orang-orang yang mengatasnamakan agama. Ketiga, masih ada kesenjangan antara idealisme agama dan praktis sosial. Keempat, dalam kehidupan beragama, masih ada kesenjangan antara ortodoksi (dimensi keimanan) dan ortopraksi (dimensi amal) (Tharaba, 2016).

Relasi sosial akan terbangun dengan indah apabila interaksi sosial itu dibangun dengan keharmonisan. Menurut Rizal Panggabean, ada empat arena yang dapat membangun keharmonisan, yakni permukiman, sekolahan, tempat kerja dan organisasi (Rizal Panggabean, 2018). Interaksi sosial dibangun untuk kelangsungan kehidupan bermasyarakat, meski dengan keragaman agama. Relasi sosial dapat terbangun karena intensifnya interaksi sosial yang berkelanjutan dengan bagus. Proses interaksi yang dilakukan secara terus menerus akan menghasilkan suatu hubungan sosial. Hubungan sosial tidak hanya terjadi dalam jarak yang dekat atau daerah yang sama, tapi juga terjadi dengan individu atau masyarakat yang berbeda daerah. Selain itu hubungan sosial juga tidak hanya terjadi dengan suku, ras dan agama yang sama, melainkan dapat juga dengan masyarakat yang berbeda suku, ras dan agama.

Hubungan antarumat agama harus bisa saling mengerti. (Kumalasari, 2020). Mufri menjelaskan bahwa makna pluralitas harus saling aktif dan harus bisa menciptakan konsensus perdamaian dengan beberapa konflik (Murfi \& Fitriyani, 2018). Diana menjelaskan dalam konteks Amerika, umat Islam, Yahudi, dan Kristen tahun 1990 menciptakan kode etik untuk saling menghormati dan menghargai umat agama dengan berlomba-lomba dalam kebaikan (L. 
Eck, 1990). Sosial budaya juga menjadi sisi untuk saling membangun. Suprapto dalam kajian Hindu Muslim mengatakan bahwa makna kebersamaan ialah membangun keharmonisan, terutama karena ada festival (Suprapto, 2015). Jangan sampai menyebarkan ketakutan dalam beragama, terutama Islam, mempunyai makna yang inklusif dan harmonis dalam ajaran agamanya (Nurul Hidayah, 2016).

Hubungan sosial antara Islam dan Kristen di Desa Sidorejo tidak pernah terjadi masalah mengenai hal agama yang berujung pada konflik. Sumarno menuturkan selaku Kasun Gumuk Kembar bahwa:

Masyarakat Sidorejo itu rukun, tidak pernah terjadi konflik. Ketika ada masalah kita samasama mencari akar masalah, bukan menambah masalah. Dusun Gumuk Kembar sendiri dengan mayoritas Muslim masyarakatnya menanamkan nilai-nilai toleransi dalam membina kerukunan umat beragama dengan tujuan untuk terciptanya masyarakat yang rukun, damai terutama seperti perayaan hari raya. Mereka saling anjangsana untuk lebih mempererat tali silaturahmi dalam kehidupan umat beragama.

Saya selaku kasun mempunyai program yakni mengadakan arisan dengan mengajak semua RT di Dusun Gumuk Kembar setiap satu bulan sekali dengan tujuan untuk saling menjalin tali silaturahmi antar umat beragama. Karena dalam arisan tersebut ada beberapa anggota yakni ada 10 orang dengan 3 orang Islam dan 7 Nasrani. Dengan tujuan bahwa silaturahmi untuk saling merukunkan diantara keberagaman agama. Bahwa arisan ini dianjurkan sekali, karena dengan arisan dengan melakukan anjangsana ke rumah teman kita akan tahu bahwa bagaimana kondisi saudara kita, dan ketika lebaran pun kita selalu melakukan anjangsana, baik ketika lebarannya umat Krstiani, maupun umat Kristiani dengan mau datang ke lebaran umat Islam (Sumarno, September 9, 2019).

Dari penuturan Sumarno, Desa Sidorejo yang beragam agamanya tidak pernah terjadi konflik yang muncul ke permukaan yang berkibat kekerasan. Ketika ada sebuah masalah yang melanda, penyelesaiannya dengan damai dan musyawarah ialah kuncinya, dengan mencari akar masalahnya bukan menambah masalah, tapi bagaimana mencari solusi untuk saling rukun, harmonis dan damai dalam hidup berdampingan dengan keragaman agama. Dengan berbagai kegiatan yang diciptakan oleh Sumarno seperti arisan anjangsana menjadi salah satu media untuk merukunkan kehidupan antarumat beragama. Kegiatan tersebut sifatnya keliling satu bulan sekali dengan mengunjungi langsung rumah yang pada waktu itu mau dikunjungi. Dengan langsung terjun ke masyarakat dan melihat kondisi kehidupan sosial ekonomi mereka saling membantu dengan memberikan dana atau sembako hasil arisan dengan tujuan untuk saling mempererat tali silaturahmi antara umat Muslim dan Kristiani.

Pandangan kemanusiaan dan sosial menjadi landasan kehidupan antarumat beragama yang rukun dan harmonis di Desa Sidorejo tersebut. Meski terjadi beberapa masalah menyangkut agama maupun individu, tapi tidak sampai terjadi ke ranah kekerasan fisik. Malahan dengan merukunkan antarumat beragama tersebut dengan saling mengunjungi ketika perayaan hari raya menjadi perekat tali silaturahmi antarumat beragama di Desa Sidorejo.

Sumbulah menjelaskan bahwa pola kerukunan antarumat beragama merupakan kedamaian dan kesejahteraan dambaan setiap manusia. Dalam rangka mencapai idaman setiap insan tersebut, diperlukan terciptanya suatu keadaan yang membentuk sebuah bangunan toleransi kerukunan umat beragama yang hakiki. Kerukunan dan toleransi yang hakiki tidak bisa dibentuk dengan cara pemaksaan dan formalisme, sebab jika demikian terjadi, maka yang ada adalah toleransi dan kerukunan "semu". Toleransi dan kerukunan sejati adalah berangkat dari kesadaran nurani dan inisiatif semua pihak yang terlibat di dalamnya (Sumbulah \& Nurjanah, 2013). Konsep yang unik penulis ambil dari Taufani bahwa proses sosial terbentuk dari interaksi sosial. Ini bisa diterapkan oleh umat Islam, meskipun kajian Taufani kepada Sunni Syi’ah (Taufani, 
2020).

Masyarakat Sidorejo merupakan masyarakat yang plural dengan agamanya. Interaksi sosial merupakan kunci dalam menjalin hubungan sosial yang indah dengan beragamnya agama tersebut. Dengan menjalin interaksi sosial yang bagus dalam kehidupan antarumat beragama dan saling percaya satu sama lain tidak saling mencurigai mengenai hal-hal apapun sehingga kehidupan akan berjalan dengan rukun dan harmonis. Selaras dengan dikatakan Lestari bahwa wujud kerukunan atau toleransi antarumat agama akan terlaksana apabila interaksi antarumat agama untuk tidak saling merugikan (Lestari, 2020). Adapun bentuk relasi sosial yang dapat menjadikan rukun dan harmonis dalam kehidupan masyarakat Sidorejo ialah sebagai berikut:

Gotong Royong. Dalam kehidupan masyarakat Sidorejo yang beragam, gotong royong merupakan konsep kehidupan nomor satu dalam merawat keharmonisan. Seperti mendirikan rumah ibadah, baik gereja maupun masjid mereka antusias untuk saling gotong royong dalam mendirikan tempat ibadah. Kenapa? Karena dengan saling gotong royong dalam membangun tempat ibadah atau hal-hal lain pasti tertanam jiwa-jiwa sosial yang tinggi sesama umat beragama maupun antarumat beragama karena memandang umat beragama lain di Desa Sidorejo itu bukan musuh atau lawan, mereka saudara, kawan dengan konsep kemanusiaan atau humanis dalam sikap yang tertanam pada masyarakat Desa Sidorejo. Bukan konsep teologis yang kemudian memandang umat lain salah, sesat dan tidak mau bertetangga dan tidak mau saling membantu yang pada akhirnya konflik dan permusuhan yang ditimbulkan. Seperti apa yang dituturkan oleh Mujiono selaku tokoh agama di Dusun Gumuk Kembar:

Kalau dilihat kerukunan tidak pernah ada macam-macam yang jelas saling menyadari, kita tidak memandang agamanya melainkan memandang kemanusiannya. Yang disana (Gumuk Kembar dekat Gereja) tidak ada bedanya sudah..artinya kalau yang punya kerepotan di Islam umat Kristen ya.. membantu dan kalau Kristen repot umat Islam membantu dalam sisi sosialnya karena kedekatan sisi kemanusiaannya (Mujiono, Juli 12, 2019).

Dalam pandangan Mujiono yang mengatakan sisi kemanusiaan ialah yang utama, bukan sisi agama untuk saling merukunkan antarumat beragama di Desa Sidorejo. Konsep tersebut yang dikemukakan Mujiono selaras dengan pandangan pluralisme agama Faisal Ismail bahwa pandangan mengenai keragaman agama setiap manusia lihatlah dengan sisi kemanusiaan atau humanis bukan dilihat dari sisi teologis yang nanti dikhawatirkan terjadinya truth claim yang kemudian muncul perpecahan karena saling mencari kebenaran masing-masing (Ismail, 2014).

Gotong royong bukan hanya pada pembangunan tempat ibadah melainkan seperti acara pengajian masyarakat Kristen antusian untuk ikut membantu. Karena semua bertujuan untuk saling membangun relasi sosial yang baik dan indah dengan harapan Sidorejo semakin harmonis kehidupan antarumat agamanya. Seperti yang diungkapkan Lina selaku kepala desa:

Di sebelah timur ada Mushola yang berdirinya setelahnya bapak kades, itu kalau ada peringatan maulud nabi selalu mengundang orang Kristen dan kerja bakti untuk mendirikan terop untuk fasilitas melaksanakan pengajian tersebut, orang nasrani ikut campur dalam mendukung kegiatan tersebut. Jadi tidak ada saling individualis dalam kehidupan keberagaman agama, semua saling bahu membahu, karena kita berangkat dari nenek moyang Islam dan Kristen, jadi rukun-rukun saja seperti nenek moyang kita dahulu, ada konflik dalam kehidupan langsung dimusyawarahkan dan tidak sampai diusut hingga terjadi konflik (Lina, Oktober 22, 2019).

Anjangsana Arisan merupakan kegiatan yang diadakan untuk lebih merekatkan kehidupan antarumat beragama. Suwarno menuturkan:

Saya selaku kasun mempunyai program yakni mengadakan arisan dengan mengajak semua RT di Dusun Gumuk Kembar setiap satu bulan sekali dengan tujuan untuk saling menjalin tali 
silaturahmi antar umat beragama. Karena dalam arisan tersebut ada beberapa anggota yakni ada 10 orang dengan 3 orang Islam dan 7 Nasrani. Dengan tujuan bahwa silaturahmi untuk saling merukunkan diantara keberagaman agama. Bahwa arisan ini dianjurkan sekali, karena dengan arisan dengan melakukan anjangsana ke rumah teman kita akan tahu bahwa bagaimana kondisi saudara kita, dan ketika lebaran pun kita selalu melakukan anjangsana, baik ketika lebarannya umat Kristiani, maupun umat Kristiani dengan mau datang ke lebaran umat Islam (Sumarno, September 9, 2019)

Kegiatan anjangsana arisan tersebut merupakan kegiatan sosial yang bertujuan untuk menyambung tali silaturahmi antarumat beragama. Namun kemasan yang ditunjukkan ialah dengan bingkai kegiatan anjangsana arisan. Ketika anjangsana dimulai di rumah warga, terutama perangkat desa, di situ terjadilah sebuah interaksi sosial antara umat Muslim dan Kristiani untuk bersilaturahmi dan sekaligus untuk mendekatkan secara sosial ekonomi dengan melihat kondisi rumah dan kehidupan masyarakat di situ bisa langsung meninjau lokasi kehidupan mereka, sehingga arisan tujuan akhirnya ialah untuk membantu sesama dalam perekonomian yang dikemas dalam bingkai silaturahmi. Adapun anggota arisan tersebut ialah 10 orang, 3 Muslim dan 7 Kristen. Maksud tujuan anjangsana arisan ini untuk mempererat dan merukunkan antarumat beragama, sambung silaturahmi untuk berlangsungnya kehidupan yang harmonis untuk masa depan.

Perayaan Hari Raya. Dalam perayaan hari raya, baik Hari Raya Idul Fitri, maupun Hari Raya Natal, umat Muslim dan Kristiani saling kunjungan. Mereka tidak pernah terbatasi oleh agama, ketika hari raya Idul Fitri, umat Kristiani juga bersilaturahmi ke rumah warga Muslim, ketika hari raya Natal, umat Muslim pun hadir dalam perayaan tersebut. Tujuan dan maksud untuk menghadiri perayaan hari raya tersebut ialah, untuk saling mempererat tali silaturahmi di antara kedua belah pihak agama untuk tidak saling menjelekkan satu sama lain, saling membuka diri bukan menutup diri, sehingga harmonislah yang tercipta. Dalam penuturan Mbah Mungin selaku tokoh masyarakat:

Natalan itu begini mas, jadi orang Islam ya Kristen, orang Kristen juga ke Islam. Pokoknya rukun antara Islam dan Kristen. Ketika hari raya saya ke lading, hari raya pak di tempatmu (Kristen)? Iya pak nanti anakmu suruh hadir (untuk silaturahmi sebagai bentuk kehormatan) ke hari raya ku (natalan), aku ya datang ke hari rayamu (Islam). Jadi ada timbal balik kayak gitu. Tidak ada sentiment dan damai-damai aja tidak ada perbedaan-perbedaan semua saling silaturahmi (Mungin, November 22, 2019)

Dalam artian untuk saling menghormati dan sebagai ajang silaturahmi atau anjangsana antarumat beragama. Kehidupan mereka saling toleransi, tidak membatasi diri, mereka sama-sama masyarakat Desa Sidorejo yang ingin mewujudkan desa yang damai dengan adanya dua agama (Lina, Oktober 22, 2019).

Wahid Foundation melaporkan pada 05 September 2019, telah menangkap fenomena pelanggaran-pelanggaran terhadap kemerdekaan warga negara. Selama kurun waktu 2018 Wahid Foundation menemukan beberapa temuan penting. Misalnya, negara menjadi aktor pelanggar paling banyak tetapi juga menempati posisi tertinggi dalam praktik baik. Wahid menyebutkan pada tahun 2018 terdapat 192 peristiwa, 276 tindakan, negara 130 pelanggaran, non-negara 146 pelanggaran. Setidaknya ada 10 wilayah dengan kasus pelanggaran yakni DKI Jakarta, Jawa Barat, Jawa Timur, Banten. Aceh, Jawa Tengah, Sumatera Utara, Sumatera Selatan, Jambi, dan Riau. Adapun bentuk tindakan yang menempati kurva paling atas ialah pemidanaan berdasarkan agama/keyakinan, penyesatan agama/ keyakinan, pelarangan aktivitas, ujar kebencian, diskriminasi agama, pemaksaan agama, pembatasan/pelarangan kegiatan agama, serangan fisik/perusakan properti, pemaksaan penaatan agama, perusakan rumah agama, pelarangan simbol, pembiaran, pembatasan, penutupan dan penyegelan rumah ibadah, intimidasi dan 
ancaman. Ini perlu kemudian di atasi dengan menciptakan langkah dalam mengatasi ekstremisme kekerasan dalam ranah agama-agama. (Indah Budi Ekayati \& Darojatul Aliah, 2018; "Presentasi Laporan Kemerdekaan Beragama Berkeyakinan," 2018).

\section{Upaya Muslim-Kristiani dalam Merawat Keharmonisan di Desa Sidorejo}

Memang bagi mayoritas Islam Indonesia, baik tradisionalis maupun modernis, tak semua sepakat dengan pluralisme. Sebagai kelompok mayoritas, Islam harus menjadi wadah bagi kehadiran keluarga dalam iman. Yang paling krusial pada hubungan antarumat agama ialah ketika Muslim masuk ke gereja. Dipastikan ada batasan-batasan dalam menyikapi hubungan tersebut. Selama hubungan itu baik, dan tidak ada pemaksaan atau mendiskreditkan agama lain, tidak ada problem yang harus dirisaukan. Dari kajiankajian ilmiah dan tukar wawasan, pengalaman tentang lintas agama itulah, dipastikan akan tumbuh kehidupan yang rukun dan harmonis dalam kubangan kemajemukan agama di dunia terkhusus di Indonesia.

Merawat keharmonisan dalam masyarakat yang beragam agama termasuk Sidorejo, membutuhkan sebuah upaya yang amat indah dalam mempersatukannya. Keharmonisan antarumat beragama seperti yang ada pada masyarakat Sidorejo sudah terjalin lama dan menjadikan rentang sejarah dalam kehidupan mereka. Sejak datangnya umat Kristiani di Desa Sidorejo, di sana sudah ada beberapa kelompok penganut agama Islam. Sehingga mereka sudah terbiasa dengan pluralitas agama dengan lingkup pedesaan. Kemudian keharmonisan sudah terjalin lama, umat Muslim dan Kristiani dalam merawatnya.

Langkah-langkah untuk mencapai kerukunan seperti itu, memerlukan proses waktu serta dialog, saling terbuka, menerima dan menghargai sesama, serta cinta kasih. Perlu ditegaskan bahwa kerukunan hidup antarumat beragama bukan berarti merelatifikasi agama-agama yang ada dengan melebur kepada satu totalitas atau menjadikan agama-agama yang ada itu sebagai unsur dari satu agama baru sinkretisme. Dengan kerukunan dimaksudkan agar terbina dan terpeliharanya hubungan baik dalam pergaulan antara warga yang berlainan agama. Urgensi kerukunan adalah untuk mewujudkan kesatuan pandangan dan kesatuan sikap, guna melahirkan kesatuan perbuatan dan tindakan serta tanggungjawab bersama. Seperti yang dituturkan oleh Joko selaku tokoh agama Kristen:

Memberi motivasi, qobilah, kebaktiankebaktian dalam Kristen, pengajian untuk menumbuhkembangkan rasa persatuan dan kesatuan, walaupun toh itu keyakinan berbeda tetapi inilah Sidorejo uniknya itu. Jadi tetap mulai dulu sampai sekarang mulai berdirinya desa Sidorejo, bukan hanya orang Kristen saja, melainkan Muslim pun berjuang untuk bersama-sama membangun Sidorejo.

Sesuai dengan apa yang diyakini apa yang dipercaya itu mempunyai prinsip masingmasing (prinsip nya orang Nasrani begini, prinsipnya orang Islam begini, tetapi tidak saling benturan karena keharmonisan itu terjadi karena seringnya kita melakukan interaksi antar tokoh utamanya. Jadi prinsipnya meski ada dua agama Islam dan Kristen ayo kita wujudkan Sidorejo seperti Indonesia yang bersemboyan bhinneka tunggal ika, ya walaupun berbedabeda ya inilah indonesia, seperti Sidorejo ayo kita bangun bersama-sama untuk mewujudkan dan menumbuhkembangkan Sidorejo supaya menjadi Sido=jadi, Rejo=rame (berkembangnya penduduk untuk berlomba-lomba dalam membangun Desa Sidorejo (Joko, November 14, 2019).

Menurutnya, membangun sebuah kehidupan jangan hanya terfokus pada pembangunan bersifat fisik, melainkan dari sisi sumber daya manusianya, bagaimana dalam diri manusia bisa tertanam sikap menghargai keberbedaan dan mampu menanamkan sikap toleransi dalam hidup antarumat beragama. Kehidupan dalam masyarakat Desa Sidorejo itu berbeda agama, tetapi dalam proses untuk 
memajukan kehidupan yang langgeng ialah dengan bersatu tanpa pandang latar belakang. Ketika desa ada sesuatu yang harus disampaikan ke masyarakat, maka dikumpulkan masyarakat di balai desa untuk berembug mengenai apa yang perlu disampaikan, sehingga tidak timbul keganjilan dan konflik, terutama mengenai agama, seperti membangun rumah ibadah, pengajian dan membangun desa untuk kemajuan bersama. Menurutnya, inilah Desa Sidorejo, dengan keragaman agamanya, tetapi tetap toleran dan rukun dalam kehidupannya. Menurut Abdul Jamil Wahab, proses harmoni dan integrasi sosial akan terbentuk jika terdapat tiga hal, yaitu pertama, pemahaman agama yang inklusif. Kedua, ketaatan pada hukum. Ketiga, memaafkan masa lalu dan ikatan antarwarga. Menurutnya, yang sering terjadi konflik ialah mulai pudarnya kearifan lokal, minimnya ruang publik atau dialog, dan memudarnya ikatan antarwarga. Menurut Abdul Jamil dikutip dari Bahrul Hayat bahwa keharmonisan umat beragama itu terwujud dalam kehidupan umat beragama jika memiliki tiga komponen, yaitu Pertama, sikap saling mengakui dan menyadari pluralitas. Kedua, adanya sikap saling menghormati (toleransi). Ketiga, sikap saling bekerja sama (Jamil Wahab, 2015).

Upaya merawat keharmonisan umat beragama di Desa Sidorejo ada beberapa cara untuk menjalin keharmonisan antarumat beragama, dengan harapan keharmonisan yang sudah terjalin lama, jangan hanya hilang karena adanya konflik atau masalah kecil dalam masyarakat mengenai agama, sehingga peran tokoh agama, tokoh masyarakat mempunyai tugas untuk saling merekatkan dan rekonsiliasi kembali untuk terjalinnya kekondusifan suasana dalam kehidupan masyarakat Sidorejo. Upaya dalam merawat keharmonisan masyarakat Sidorejo antara lain dapat penulis klasifikasikan: pertama, saling menjaga keyakinan antar umat beragama. Kedua, saling memberikan solusi ketika ada masalah, terutama terkait keagamaan. Saling silaturahmi dalam merawat dan menjaga keharmonisan antarumat beragama. Ketiga, tokoh masingmasing agama saling memahami dalam kondisinya, seperti ketika ada kegiatan Gereja, kegiatan Islam yang bernuansa suara dikecilkan untuk saling menghormati dan sebaliknya. Keempat, ketika ada masalah mengenai agama diselesaikan dengan musyawarah (Joko, November 14, 2019).

Merawat keharmonisan juga dituturkan oleh Kasun Gumuk Kembar yakni Pak Sumarno, beliau menuturkan:

Kenapa masyarakat Sidorejo rukun? Dan apa faktornya. Kita berpegang teguh pada Pancasila, kita akan merasa bahwa agama yang kita anut tidak hanya benar sendiri, sehingga kita tidak mudah untuk kemudian mengatakan agama ku yang paling benar, yang lain salah, dan itu yang nantinya akan memicu konflik atas landasan agama. Dan ketika berbicara kepercayaan itu tidak bisa dipaksakan. Seperti ajaran mulai kecil itu bersumber dari hati, meskipun Kristen mereka juga mempunyai ajaran yang mengenai hati. Yang diutamakan ialah toleransi antarumat beragama dengan tujuan untuk kita saling menghormati kepada umat Kristiani, pun sebaliknya. Dengan kita mempunyai niat bagus untuk menghormati umat lain, maka umat lain pun sama akan menghormati kita. Kalau konflikkonflik mengenai agama tidak pernah terjadi di Sidorejo, namun kalau konflik pribadi setiapa manusia itu ada itu biasa. Dan utnuk merawat keragaman terbut dengan mempercayai agama masing masing tanpa ragu dan terus menjalani, tanpa saling menjatuhkan agama lain (Sumarno, September 9, 2019).

Dari penuturan Sumarno bahwa masyarakat Sidorejo menanamkan nilainilai pancasila dalam menjalani kehidupan masyarakat yang beragam. Dengan tujuan dengan mengamalkannya dapat diserap tidak hanya agama kita yang paling benar, mereka salah, sesat, dan klaim kebenaran yang bisa menimbulkan perpecahan dan konflik antarumat beragama. Sejatinya ajaran agama itu dalam hati, bukan hanya kita mendapatkan secara fisik, tapi juga harus diserap dalam hati dan diamalkan sesuai ajaran agama masing-masing.

Fakta menunjukkan bahwa konflik komunal kadang-kadang masih terjadi, baik karena faktor ekonomi, faktor politik, kasus 
perselisihan antarsuku maupun antaragama. Dalam konteks hubungan antaragama yang merupakan aspek paling sensitif, kadang-kadang muncul kasuskasus ketegangan atau konflik yang sebenarnya tidak disebabkan oleh faktor agama semata, tetapi oleh faktor ekonomi atau politik. Karena itu usaha untuk mengembangkan toleransi dan kerukunan antarumat beragama ini telah dilakukan, baik oleh pemerintah maupun masyarakat sendiri, terutama organisasi-organisasi keagamaan dan kemasyarakatan serta tokoh-tokoh agama. Yang paling baik adalah upaya-upaya membangun toleransi, kerukunan dan keharmonisan sosial atas dasar kesadaran tanpa ada paksaan termasuk paksaan hukum. Hal ini bisa terwujud melalui proses sosialisasi, internalisasi dan institusionalisasi nilai-nilai ini dalam masyarakat. Namun, dalam kenyataan, tidak semua orang atau kelompok mau melakukan dengan penuh kesadaran, untuk mewujudkan toleransi dan kerukunan itu (Abdillah, 2011).

Menjalin kerukunan dalam kehidupan antarumat beragama memang perlu ditanamkan nilai-nilai humanis dan pluralis dalam memandang kehidupan majemuknya agama agar terjalin hubungan kehidupan yang harmonis dan rukun. Pada masing-masing agama mempunyai fungsi untuk saling menciptakan keindahan dalam kehidupan bukan untuk saling ujar kebencian. Pada dasarnya semua agama, apa pun nama dan muatan ajarannya, pada hakikatnya merupakan kekuatan positif, inspiratif, kreatif, konstruktif, sublimatif dan integratif. Agama mengajarkan perdamaian, dan kedamaian cinta kasih, kasih sayang, persahabatan, persaudaraan dan rasa perikemanusiaan yang sangat mendalam antarmanusia (Ismail, 2019).

Menelisik fungsi agama di berbagai komunitas dan sistem sosial memang berbeda-beda. Di dalam masyarakat tradisional, agama merupakan bagian yang tidak terpisahkan dari kebudayaan, menjalankan baik fungsi asketik-bersifat sederhana, jujur, fungsi integrasi maupun fungsi-fungsi lainnya. Masih dalam kaitan fungsi agama bagi kehidupan masyarakat, Nottingham membagi masyarakat menjadi tiga tipe, yang mana pendekatan ini dilakukan dengan menggunkan pendekatan sosiologi agama. Tipe pertama, adalah masyarakat terbelakang dan memiliki nilainilai sakral, tipe kedua, adalah masyarakat pra-industri yang sedang berkembang, tipe ketiga, adalah masyarakat industri sekuler (Tharaba, 2016).

Dalam menjalin kehidupan antarumat beragama dalam masyarakat Sidorejo sikap saling toleransi merupakan landasan awal dalam mengharmoniskan antarumat beragama. Bertetangga dengan umat nonmuslim sudah biasa dalam kehidupan masyarakat Sidorejo, terutama rumah mereka yang berdekatan dengan gereja. Sikap toleran, saling menghargai sangat ditanamkan dalam kehidupan masyarakat Sidorejo baik individu maupun kelompok (umum) sehingga keharmonisan dan kerukunan selalu hadir dalam kehidupan masyarakat Sidorejo. Ketika ada konflik di antara mereka sesegera mungkin untuk diredakan dengan cara indah dan damai yakni musyawarah. Seperti penuturan Lina selaku Kades Sidorejo: Ketika ada konflik segera diselesaikan dengan musyawarah (Lina, October 22, 2019).

Pluralitas agama di negeri ini tidak bisa dielakkan dan ditinggalkan. Persinggungan dalam kehidupan harus menjadi realitas yang terus dibangun dalam menuju kehidupan sebagai masyarakat Indonesia yang rukun. Konflik itu sudah menjadi bagian manusia, namun, keharmonisan dan pluralisme agama harus direkonstruksi di tengah-tengah kemajemukan agama tersebut. Mutaqqin menjelaskan bahwa keragaman agama dan yang memaknainya pun beragam (Mutaqqin, 2014). Muslich menjelaskan bahwa dalam konteks keindonesiaan pluralisme agama seyogyanya harus tetap terus digalakkan (Muslich Rizal Maulana, 2020). Wacana ini harus terus dijalankan meskipun banyak penafsiran. Umam menjelaskan pluralisme ada dua pandangan yakni pluralisme teologi dan pluralisme sosial (Baeni Umam, 2019). Ginting menjelaskan bahwa menjalin 
hubungan agama harus ada perjumpaan dan komitmen (Ulina Ginting, 2014).

\section{Peran Tokoh Agama Merawat Keharmonisan}

Perilaku seorang individu atau kelompok yang eksklusif terhadap sebuah pendapat dari yang lain mereka akan merasa harus benar sendiri. Perilaku umat beragama yang eksklusif, Ruslan menjelaskan sangat terkait dengan truth claim dan salvation claim yang pada gilirannya dapat mengambil bentuk-bentuk tindakan agresif dan demonstratif sehingga sangat membahayakan masa depan umat beragama sendiri termasuk bangsa ini. Imro menambahkan bahwa idealitas pluralisme agama masih belum nampak, karena masih adanya truth claim pada tataran teologis. Ditakutkan, lambat laun ketegangan akibat eksklusifisme tersebut akan melahirkan konflik antarumat beragama (Azizah et al., 2020; Ruslan, 2020).

Peran masyarakat dalam merawat keharmonisan menjadi sebuah hak yang wajib bagi seluruh elemen lapisan masyarakat Sidorejo. Peran seorang aktor dalam merawat keharmonisan bukan hanya dilakukan oleh yang mempunyai jabatan atau nama di desa, melainkan semua lini dalam kehidupan masyarakat Sidorejo agar tercipta kehidupan yang harmonis dan rukun. Aktor humanis ini sangat penting dalam mendakukan diri sebagai perekat di tengah kemajemukan agama. Banyak yang berperan dalam ikut serta merawat keharmonisan di Desa Sidorejo, bisa penulis klasifikasikan antara lain: tokoh agama, tokoh masyarakat, dan masyarakat umum.

Peran tokoh agama dalam merawat keharmonisan di Desa Sidorejo terutama dalam agama Islam menanamkan nilai-nilai humanis, toleransi dalam menjalani kehidupan bermasyarakat dengan umat non-muslim. Islam menjunjung tinggi toleransi dengan konsep toleransi beragama dalam Islam bukanlah membenarkan dan mengakui semua agama dan keyakinan yang ada saat ini, kerena ini merupakan persoalan akidah dan keimanan yang harus dijaga dengan baik oleh setiap pribadi muslim. Toleransi bukan mengakui semua agama sama, apalagi membenarkan tata cara ibadah umat beragama lain (Rusydi \& Zolehah, 2018).

Toleransi yang telah menjadi tradisi akan mampu mewujudkan kehidupan yang harmonis sekaligus menepis penilaian bahwa Indonesia adalah Negara yang rentan terhadap konflik antaragama (Naim, 2016). Ditinjau dalam fakta sejarah bahwa toleransi juga dapat ditunjukkan melalui Piagam Madinah. Piagam ini adalah satu contoh mengenai prinsip kemerdekaan beragama yang pernah dipraktikkan oleh Nabi Muhammad SAW di Madinah. Di antara butir-butir yang yang menegaskan toleransi beragama adalah sikap saling menghormati di antara agama yang ada dan tidak saling menyakiti serta saling melindungi anggota yang terikat dalam Piagam Madinah. Sikap melindungi dan saling menolong tanpa mempersoalkan perbedaan keyakinan juga muncul dalam sejumlah hadis dan praktik Nabi.

Peran sebagai tokoh agama yang paling penting dalam mengembangkan nilai toleransi di masyarakat yaitu, pertama, ikut serta dalam upaya menyelesaikan konflik internal umat beragama maupun antar umat beragama. Dalam upaya menyelesaikan konflik, baik internal maupun antar umat beragama, peran seorang tokoh agama sangat dibutuhkan karena biasanya yang dapat masuk terlebih dahulu ke masyarakat ialah tokoh agama, karena tokoh agama berperan aktif dalam menjaga kerukunan internal umat beragama. Kedua, tokoh agama menjadi sebuah teladan bagi umat yang dipimpin dan mengajak masyarakat untuk saling mengasihi, walaupun berbeda keyakinan.

Dalam upaya untuk memantapkan kerukunan antar umat beragama, hal serius yang harus diperhatikan adalah fungsi pemuka agama, tokoh masyarakat, dan pemerintah. Tokoh agama merupakan figur yang dapat diteladani dan dapat membimbing dengan apa yang diperbuat pasti akan diikuti oleh umatnya dengan taat. Peran yang dimiliki oleh tokoh agama yang dimaksud di sini adalah mencakup 
peraturan yang membimbing masyarakat. Tokoh agama (kiai) berperan penting dalam mengelola kesejahteraan masyarakat dan sosial keagamaan, namun kiai juga terjun dalam kegiatan pertanian, di ladang, untuk mengetahui keadaan sosial masyarakatnya. Pandangan kerukunan antarumat beragama dalam kehidupan masyarakat Desa Sidorejo juga dituturkan oleh Mujiono selaku tokoh agama di Dusun Gumuk Kembar:

Kalau dilihat kerukunan tidak pernah ada macam-macam yang jelas saling menyadari, kita tidak memandang agamanya melainkan memandang kemanusiannya. Yang disana (Gumuk Kembar dekat Gereja) tidak ada bedanya sudah..artinya kalau yang punya kerepotan di Islam umat Kristen ya.. membantu dan kalau Kristen repot umat Islam membantu dalam sisi sosialnya karena kedekatan sisi kemanusiaannya (Mujiono, Juli 12, 2019).

Dalam pandangan Mujiono kerukunan antarumat agama itu harus dijaga. Kita saling membantu sesama umat agama maupun antarumat beragama dengan menanamkan prinsip kemanusiaan dalam melihat keragaman agama, yang nantinya timbul keharmonisan antarumat beragama. Keragaman agama bukan menjadi penghalang untuk terus mengekspresikan kehidupan yang harmonis dan toleransi dalam setiap tindakan dan memberi kebebasan beragama kepada setiap manusia dan tidak ada paksaan. Tiap pemeluk agama mendapatkan kesempatan untuk menjalankan agama dan menciptakan kehidupan beragama sesuai dengan ajaran agama masing-masing. Pengembangan agama dan kehidupan beragama tidak boleh menjurus ke arah tumbuhnya pemikiran dan pemahaman agama yang sempit karena hal ini akan menimbulkan konflik antar agama (Nisvilyah, 2013).

Hubungan antara muslim dan penganut agama lain tidak dilarang dengan syariat Islam, kecuali bekerja sama dalam persoalan aqidah dan ibadah. Kedua persoalan tersebut merupakan hak intern umat Islam yang tidak boleh dicampuri pihak lain, tetapi aspek sosial kemasyarakatan dapat bersatu dalam kerja sama yang baik. Manusia sebagai makhluk sosial memerlukan hubungan yang harmonis dengan sesamanya. Umat Islam perlu melakukan upaya agar toleransi dapat ditegakkan dan dibina dengan kokoh melalui empat pilar, antara lain: Taaruf, Tafahum, Ta'awun dan Takaful. Dalam konsep kehidupan umat Muslim mengajarkan trilogi persaudaraan (Ukhuwah Islamiyah, Ukhuwah Wathaniyah dan Ukhuwah Insaniyah) (Ismail, 2019).

Peran umat Islam dalam merawat keharmonisan merupakan sebuah kewajiban. Dalam pandangan Faisal Ismail, sebagai seorang Muslim kita harus menanamkan visi Muslim Pluralis-Humanis dalam diri masing-masing individu, baik pelajar, mahasiswa dan individu umat Muslim terutama pendakwah. Bahwa dalam penyampaian suatu ceramah bukan ujar kebencian yang disampaikan, melainkan sebuah keharmonisan yang ditanamkan dalam hati jamaah. Sebuah konsep dalam Islam yang dijelaskan di buku Fikih Lintas Agama bahwa terdapat konsep dalam melihat dan menyikapi kehidupan dengan beragamnya agama. Di antaranya konsep tersebut adalah Ahl al-Dzimmah, Jizyah (A. Sirry, 2005).

Mutahhari menjelaskan bahwa sejauh menyangkut pluralisme sosial, Islam berusaha untuk hidup berdampingan secara damai dan saling toleran antar orang-orang yang berbeda agama dan budaya (Murtadha Mutahhari, 2006). Zayed mengatakan istilah pluralisme digunakan untuk mencakup banyak aspek masyarakat yang bersangkutan-etnis, ideologi politik, teori ekonomi, jenis kelamin, dan agama. Istilah pluralisme agama yang kini marak digunakan, mencerminkan berbagai realitas dan makna yang berbeda (Tayseer Mohammad, n.d.). Konsep pluralisme pun berkembang pasca kemunculan konsep masyarakat madani, termasuk di Indonesia (Saihu, 2019). Menarik lagi ketika mengambil istilah pluralisme dari Talib yang dikutip oleh Rinto bahwa konsep pluralisme merupakan pertalian sejati kebhinekaan dalam ikatan-ikatan keadaban, selaras 
dengan Gus Dur bahwa pluralisme harus ada sisi kemanusiaan (Hasiholan Hutapea \& Iswanto, 2020) (Basuni, 2015), (Taufani, 2018).

Dalam pandangan agama Kristen, kita harus saling menjaga kerukunan dengan menanamkan nilai-nilai kerukunan antarumat beragama di dalam majelis Gereja.

Dengan menanamkan nilai-nilai kerukunan antarumat beragama di dalam gereja yang dibentuk pada majelis-majelis di gereja, ketika perayaan hari-hari besar dari umat Islam umat Kristiani berkunjung ke rumah-rumah warga, maupun perangkat desa. Untuk apa? Untuk menjalin kerukunan antarumat beragama, menjalin silaturahmi agar tercipta masyarakat Sidorejo yang rukun dan damai. Peran tokoh-tokoh dalam Kristen juga tinggi dalam mengkoordinir jemaatnya untuk terus menanamkan nilai kerukunan antarumat beragama. Dalam merawat keharmonisan menurut Joko selaku tokoh umat Kristiani dan perangkat desa menerangkan bahwa:

Kita harus tahu tugas dan fungsi masingmasing, terutama tokoh agama, masyarakatnya antara Islam dan Kristiani itu bahkan tidak tiap tahun, tapi dua tiga kali pertahun, semisal ada acara pengajian yang Kristiani diundang, Natalan yang Muslim diundang, itulah cara untuk merawat keharmonisan, walaupun berbeda keyakinan, pemahaman, tapi kita tetap satu, yaitu desa Sidorejo. Saling mengerti, menerima dan memberi masukan kepada masyarakat Sidorejo, biar masyarakat tahu, bahwa umat Kristiani kalau minggu ke gereja, kalau muslim ke masjid, sehingga peran-peran tokoh masyarakat, tokoh agama itu sangat kental sekali untuk mewujudkan masyarakat (Joko, November 14, 2019).

Dalam pandangan Joko, merawat keharmonisan dalam pluralitas agama merupakan suatu keharusan. Karena Sidorejo yang merupakan desa ada dua agama sejak dahulu damai, rukun sehingga ketika terjadi konflik langsung ambil sikap selesaikan dengan musyawarah. Dalam kehidupan umat beragama tokoh agama menjadi aktor utama dalam mengkoordinir kerukunan umat secara spiritual, terutama di Kristen. Seperti dituturkan Joko, peran seorang tokoh agama dalam merawat kerukunan antarumat beragama: Ya...saling berkunjung, silaturahmi setiap hari-hari besar keagmaan baik Islam maupun Kristen.

Anjangsana atau silaturahmi ke umat Islam merupakan salah satu agenda umat Kristiani. Pun sebaliknya di dalam umat Islam. Karena itu untuk menumbuhkan sikap saling toleran antarumat beragama. Terutama peran tokoh agama sangat mempengaruhi umat beragama dalam hidup bersama dalam keberbedaan. Dalam pandangan Fajar selaku pendeta di GKJW Sidorejo menuturkan:

Hubungan masyarakat Sidorejo itu rukun, kalau di Krajan itu mayoritas Kristiani dan kalau mau majemuk di Gumuk Kembar. Ya kalau keharmonisan atau relasi kita saling menghormati, memang belum banyak kegiatan yg eee di lakukan bersama-sama, kan biasanya indikasinya itu sering bertemu, ya paling kegiatan sifatnya umum, ada kegiatan desa ya saling membantu tapi kalau masyarakat ya guyub-guyub, saling njogo dalam artian yo owes, Kristen-Islam yo wes. Ya.. Natalan kita saling mengundang, misalnya idul fitri kita saling mengunjungi gentenan. Pas Natal umat Kristiani open house, siapa aja yang mau datang (F. Hari, April 25, 2020).

Peran masyarakat Sidorejo dalam merawat keharmonisan sudah barang tentu menjadi kebiasaan yang harus tertanam dalam kehidupan mereka. Masyarakat yang tidak mempunyai jabatan atau kedudukan di Desa Sidorejo juga mempunyai peran sebagai aktor dalam merawat keharmonisan, terutama mereka yang berdekatan dengan tetangga Muslim maupun Kristiani. Terutama membahas mengenai rumah tempat tinggal, hewan peliharaan umat Kristiani dan faktor pendukung terciptanya keharmonisan antara agama Islam dan Kristen di Sidorejo. Mengenai rumah yang ada di Desa Sidorejo terutama di wilayah Dusun Gumuk Kembar yang berdekatan dengan gereja dan musholla, tidak ada perbedaan dengan rumah, baik Islam maupun Kristen. Seperti ungkapan Weni; 
Membangun rumah tidak ada bedanya, membangun gini ya gini, seumpama membangun rumah ini islam ini kristen, ya tidak ada apa-apa. Depan sana ada rumah terjepit itu islam, ya kalau ada kumpulan ya $i k u t$, ada arisan ya ikut, gitu, tidak ada apa-apa. Di sini tidak asli Kristen aja, ya ada Islamnya (Weni, April 14, 2020).

Adapun faktor yang menjadi pendukung dalam kehidupan umat Muslim dan Kristiani dapat harmonis mereka saling membaur dalam kehidupan sehari-hari selayaknya masyarakat biasanya. Seperti ungkapan Winto: Yang saya lihat antara kebiasaan sehari-hari, misalnya di sawah, tanam menanam, di ladang tidak ada masalah, situ memelihara anjing tidak ada masalah (Winto, April 14, 2020). Mengenai faktor pendukung juga diungkapkan oleh Weni selaku umat Kristiani;

Pokok manusia itu tidak bawel gini gini, tidak ada. Kalau mau ke situ (ke rumah warga) masih sore main ke sini yang sini ke sana ya tidak ada apa-apa. Ya membicarakan mengenai petani, pokok tidak membicarakan agama, malah membuat permasalahan kecil gitu loh. Menurut saya di sini ya gitu, meski ada natalan ya samasama berkunjung. Di musholla ada pengajian ya sama diundang ya budal, tidak gini-gini, tidak. Natalan, paskahan diundang semua, ya datang atau tidak yang penting diundang, tapi banyak yang datang ternyata. Maka dari itu kalau orang Kristen kalau diundang ya sama datang tidak ada masalah apa-apa pokok adem, ayem dan tentrem (Weni, April 14, 2020).

Mengenai hewan peliharaan dari Kristiani juga tidak dipermasalahkan oleh umat Muslim yang hidup langsung berdekatan dengan mereka, itu merupakan bentuk bagaimana hubungan untuk saling menjaga toleransi, tidak saling menyakiti, tidak kemudian memukul dan menyakiti anjing, melainkan membiarkan, itulah bentuk peran masyarakat dalam merawat keharmonisan, dari hal-hal yang kecil tapi berdampak besar dalam kehidupan. Kata Bu Weni selaku masyarakat Sidorejo "wonten anjing nggeh mendel mawon". Kata Pak Winto "kalau masalah anjing di sini tidak ada masalah".
Peran-peran aktor dalam merawat keharmonisan pada masyarakat Sidorejo yang beragam mereka semua ikut berpartisipasi aktif dalam merajut kerukunan antarumat beragama di Desa Sidorejo. Dalam merawat keharmonisan antarumat beragama peran-peran aktor merupakan garda terdepan, terutama seluruh lini masyarakat Sidorejo. Uniknya juga dalam penelitian ini bahwa perawat keharmonisan agama bukan hanya milik tokoh agama saja melainkan bagaimana masyarakat biasa yang tidak mempunyai jabatan apa-apa juga mempunyai peran dan andil besar dalam membangun keharmonisan.

\section{Kesimpulan}

Relasi sosial juga disebut hubungan sosial yang merupakan interaksi (rangkaian tingkah laku) yang sistematik antara dua orang atau lebih. Relasi sosial merupakan hubungan timbal balik antara individu yang satu dengan yang lain dan saling memengaruhi. Relasi sosial akan terbentuk dari sebuah interaksi sosial yang dilakukan dalam kehidupan keseharian. Dalam masyarakat Sidorejo yang rukun dan damai menumbuhkan sikap saling percaya dalam menjalani kehidupan. Terutama dalam hal peribadatan, mereka saling toleran untuk tidak mengeraskan suara dalam kegiatan dan hal apapun. Merawat kerukunan dalam masyarakat Sidorejo yaitu saling mempercayai dalam kehidupan, bukan malah saling menyakiti. Merawat keharmonisan umat beragama di Desa Sidorejo tetap terjaga dan terawat dengan indah, dengan menerapkan prinsip hidup: saling menjaga keyakinan antarumat beragama, saling memberikan solusi ketika ada masalah, terutama terkait keagamaan, saling silaturahmi dalam merawat dan menjaga keharmonisan antarumat beragama, tokoh masing-masing agama saling memahami dalam kondisinya, seperti ketika ada kegiatan Gereja, kegiatan Islam yang bernuansa suara dikecilkan untuk saling menghormati, ketika ada masalah mengenai agama diselesaikan dengan musyawarah. 


\section{Ucapan Terima Kasih}

Penulis ucapkan terima kasih kepada seluruh masyarakat Desa Sidorejo yang telah membantu dalam penggalian data selama penelitian.[]

\section{Daftar Pustaka}

A. Sirry, M. (Ed.). (2005). Fiqih Lintas Agama: Memambangun Masyarakat InklusifPluralis. Paramadina.

Abdillah, M. (2011). Islam dan Dinamika Sosial Politik Di Indonesia. PT Gramedia Pustaka Utama.

Ananta Devy, D. (2009). Toleransi Beragama,. CV Pamularsih.

Azizah, I., Kholis, N., \& Huda, N. (2020). Model Pluralisme Agama Berbasis Kearifan Lokal Desa Pancasila di Lamongan. Fikrah: Jurnal Ilmu Aqidah Dan Studi Keagamaan, 8(1), 1-24. https:/ /doi.org/DOI: 10.21043/fikrah.v8i1. 7881

Baeni Umam, M. (2019). Corak Pemikiran Pluralisme Dawam Raharjo [Tesis]. UIN Sunan Kalijaga.

Basuni, A. (2015). AKTUALISASI PEMIKIRANPLURALISME KH. ABDURRAHMANStudi Program Pendidikan Pluralisme The Wahid Institute [Tesis]. UIN Syarif Hidayatullah.

Casram. (2016). Membangun Sikap Toleransi Beragama Dalam Masyarakat Plural. Wawasan: Jurnal Ilmiah Agama Dan Sosial Budaya, 01(2). https://doi.org/DOI: http://dx.doi.org/ 10.15575/jw.v1i2.588.

Cornelius Kaha, S. (2020). Dialog Sebagai Kesadaran Relasional Antar Agama: Respons Teologis Atas Pudarnya Semangat Toleransi Kristen-Islam Di Indonesia. Abdiel: Jurnal Khazanah Pemikiran Teologi, Pendidikan Agama Kristen Dan Musik Gereja, 04(2). https:/ /doi.org/DOI: 10.37368/ja.v4i2.165.

Fitriani, S. (2020). Keberagaman dan
Toleransi Antar Umat Beragama. Analisis: Jurnal Studi Keislaman, 20(2). https://doi.org/DOI: http://dx.doi.org/ 10.24042/ ajsk. v20i2.5489.

Hasiholan Hutapea, R., \& Iswanto. (2020). Potret Pluralisme Agama Dalam Masyarakat Di Kota Kupang. Jurnal Dialog Kemenag, 43(1). https://doi.org/ DOI: https://doi.org/10.47655/ dialog.v43i1.363 ।

Huda, M. T., \& Sinta Ilva Sari, R. (2020). Toleransi dan Praktiknya Dalam Pandangan Agama Konghucu. JSA: Jurnal Studi Agama, 04(1). https:// doi.org/DOI https://doi.org/10.19109/ jsa.v4i1.6159.

Indah Budi Ekayati, M., \& Darojatul Aliah, S. (2018). Menghalau Ekstremisme: Konsep E Strategi Mengatasi Ekstremisme Kekerasan di Indonesia. Wahid Foundation.

Ismail, F. (2014). Dinamika Kerukunan Antar Umat Beragama. Remaja Rosdakarya.

Ismail, F. (2019). Islam Konstitusional dan Pluralisme: Memperkuat Fondasi Kebangsaan dan Merawat Relasi Kebinekaan. IRCiSoD.

Jamil Wahab, A. (2015). Harmoni di Negeri Seribu Agama: Membumikan Teologi dan Fikih Kerukunan. PT ELex Media Komputindo.

Kumalasari, R. (2020). Religious Community Interest: A Study of Religious Plurality in Southeast Aceh. Liwaul Dakwah: Jurnal Kajian Dakwah Dan Masyarakat Islam, 10(2). https://ejurnal. iain lhokseumawe.ac.id/index.php/liwauldakwah

L. Eck, D. (1990). A New Religious America: How a "Christian Country" Has Become the World's Most Religiously Diverse Nation.

Lestari, J. (2020). Pluralisme Agama di Indonesia: Tantangan dan Peluang Bagi Keutuhan Bangsa. Al-Adyan: Journal of Religious Studies, 1(1). https:/ /doi.org/DOI: https:/doi.org/10.15548/ 
al-adyan.v1i1.1714

M. Akmansyah. (2016). Membangun Toleransi Dalam Perspektif Pendidikan Spiritual Sufistik. Kalam: Jurnal Fakultas Ushuluddin Dan Studi Agama., 10(2). https://doi.org/DOI: https://doi.org/ 10.24042/klm.v10i2.12.

Murfi, A., \& Fitriyani. (2018). Islam Nusantara: Religion Dialectic and Cultural for Pluralism-Democratic Society. ICSEAS: International Conference on South East Asia Studies, 3(5), 44-52. https://doi.org/DOI 10.18502/kss.v3i5.2324

Murtadha Mutahhari, A. (2006). ISLAM AND RELIGIOUS PLURALISM. World Federation of Khoja Shia Ithna-Asheri Muslim Communities.

Muslich Rizal Maulana, A. (2020). Problematika Pluralisme Agama Antara Teologi dan Filsafat: Membaca Kritik Marianne Moyaert atas John Hick. Jurnal Studi Agama Dan Masyarakat, 15(2). https://doi.org/ DOI:10.23971/jsam.v16i2.2136

Mutaqqin, A. (2014). Rekonstruksi Gagasan Pluralisme Agama(Telaah atas Buku Pluralisme Agama, Musuh agamaagama Karya Adian Husaini). AlAdyan: Jurnal Studi Lintas Agama, 9(1). https://doi.org/10.24042/ajsla.v9i1.1409

Naim, N. (2016). Abdurrahman Wahid: Universalisme Islam dan Toleransi. Kalam: Jurnal Fakultas Ushuluddin Dan Ilmu Agama, Vol. 10(2), 426. https:// doi.org/10.24042/klm.v10i2.8).

Nisvilyah, L. (2013). Toleransi antarumat beragama dalam memperkokoh persatuan dan kesatuan bangsa (studi kasus umat Islam dan Kristen Desa Segaran Kecamatan Dlanggu Kabupaten Mojokerto). Jurnal Kajian Moral Dan Kewarganegaraan, Vol. 2(1), 3-4.

Nurul Hidayah, A. (2016). Reversing Islamophobia Perspective through Tolerance Principle in Islam. Proceeding of the 2nd International Seminar and Conferenceon Global Issues (ISCoGI) 2016: Europeanand Asian in the Age of Globalization: Cooperation and Challenge. www.iscogi.unwahas.ac.id

Pangeran, I. (2017). Toleransi Beragama Sebuah Keniscayaan Bagi Muslim Dalam Hidup Bermasyarakat. AlMishbah: Jurnal Ilmu Dakwah Dan Komunikasi, 13 (1). https:// almishbahjurnal.com/index.php/almishbah/article/view/76.

Penyusun Desa Sidorejo, T. (2016). RPJMDes (Rencana Pembangunan Jangka Menengah Desa) Desa Sidorejo, tahun 2016-2019. RPJMDes Kabupaten Jember.

Presentasi Laporan Kemerdekaan Beragama Berkeyakinan. (2018). Www.Wahidfoundation.Org. https:// wahidfoundation.org/index.php/ publication/detail/Presentasi-Laporan$\mathrm{K}$ e $\mathrm{m}$ e $\mathrm{r}$ d e $\mathrm{k}$ a $\mathrm{a} n$ BeragamaBerkeyakinan-WahidFoundation-2018

Rahman, M. T. (Ed.). (2021). Toleransi Beragama dan Harmonisasi Sosial. Penerbit LeKKas.

Rizal Panggabean, S. (2018). Konflik Dan Perdamaian Etnis Di Indonesia. Pustaka Alvabet.

Ruslan, I. (2020). Konstribusi LembagaLembaga Keagamaan Dalam Pengembangan Toleransi Antar Umat Beragama di Indonesia. Arjasa Pratama.

Rusydi, I., \& Zolehah, S. (2018). Makna Kerukunan Antar Umat Beragama Dalam Konteks Keislaman dan Keindonesiaan. Al-Afkar: Journal for Islamic Studies, Vol. 01(01), 172-173. https://d oi .org/10.31943/ afkar_journal.v1i1.13

Saihu. (2019). Pendidikan Pluralisme Agama: Kajian Tentang Integrasi Budaya dan Agama Dalam Menyelesaikan Konflik Sosial Kontemporer. Jurnal Indo-Islamika, 9(1). 
https://doi.org/DOI: https://doi.org/ 10.15408/idi.v9i1.14828

Soekanto, S., \& Soelistyowati, B. (2017). Sosiologi Suatu Pengantar. Raja Grafindo Persada.

Sumbulah, U., \& Nurjanah. (2013). Pluralisme Agama; Makna Dan Lokalitas Pola Kerukunan Antarumat Beragama. UIN Maliki Press.

Sunarto, K. (2004). Pengantar Sosiologi. Lembaga Penerbit Fakultas Ekonomi Universitas Indonesia.

Suprapto. (2015). THE THEOLOGY OF TOLERANCE IN HINDU AND ISLAM: Maintaining Social Integration in Lombok-Indonesia. Ulumna: Journal Islamic Studies, 19(2), 339-352. https:// doi.org/DO I:http://dx.doi.org/ 10.20414/ujis.v19i2.358

Taufani. (2018). Pemikiran Pluralisme Gus Dur. Tabligh: Jurnal Ilmu Komunikasi Dan Dakwah, Vol. 19(2), 202-203. https:/ /doi.org/10.24252/jdt.v19i2.7475).

Taufani. (2020). Dinamika Internal Masyarakat Muslim Minoritas: Studi atas Relasi Sunni Syi'ah di Manado [Tesis]. UIN Alauddin.

Tayseer Mohammad, Z. (n.d.). Intellectual Responses to Religious Pluralism. http:// a l h a s s a n a in . org/english / ?com=book\&id=778

Tempat Ibadah. (2021, June 21). [Homepage]. Wikipedia.Org. https:// id.wikipedia.org/wiki/Tempat_ibadah

Tharaba, F. (2016). Sosiologi Agama: Konsep, Metode, Riset dan Konflik Sosial. MADANI.

Ulina Ginting, M. (2014). Dialog dan Pluralisme Agama Dalam Pendidikan Kristiani di Sekolah Minggu Gereja Kristen Protestan Indonesia [Tesis]. Universitas Kristen Duta Wacana.

Vinkasari, E., Tri Cahyani, E., Dwi Akbar, F., \& Agus Santoso, A. P. (2020). Toleransi Antar Umat Beragama Di Indonesia Untuk Mempertahankan Kerukunan.
Prosiding HUBISINTEK, 1. https:// o j s.u d b.a c.id/ind ex.ph p/ HUBISINTEK/issue/view/129.

Wasil. (2018). Peran Pemuka Agama Dalam Memelihara Kerukunan:Studi Kasus Hubungan Islam Dan Katolik Di Desa Pabian Kabupaten Sumenep [Tesis]. UIN Syarif Hidayatullah.

Wawancara:

Hari, F. ( Sidorejo, 25 April 2020).

Joko. (Sidorejo, 14 November 2019).

Lina. (Sidorejo, 22 Oktober 2019).

Mujiono. (Sidorejo, 12 Juli 2019).

Mungin. (Sidorejo, 22 November 2019).

Sukseswati. (Sidorejo, 12 November 2019).

sumarno. (Sidorejo, 9 September 2019).

Weni. (Sidorejo, 14 April 2020).

Winto. (Sidorejo 14 April 2020). 